\title{
Research Paper Trends in arrivals and prices of onion in Pune market
}

See end of the paper for authors' affiliations

Correspondence to :

K.S. DAUNDKAR

K.K. Wagh College of

Agriculture, NASHIK (M.S.)

INDIA

Paper History :

Received : 17.09.2014;

Revised : 24.06.2015;

Accepted : 23.07.2015
AbSTRACT : It is believed that, with the increase in arrivals of agricultural commodity in the market, their prices come down and vice versa. For this study, the data on arrivals and prices was under taken up. For the study, the data available in monthly reports of Agricultural Produce Committee Pune market, for the period of 10 years was used, the annual compound growth rate of arrivals in case of onion (4.42) were found positive and annual compound growth rates of prices in the onion (13.03) were positive growth rate indicating thereby positive relationship in Arrivals and prices per annually. Arrivals were noticed highest during the month of February (15.01) followed by March. It means that the market was flooded with onion from January to March. The lowest indices of arrivals were noticed in the month of September (5.43). The indices of lower arrivals were from August to November. In case of price indices was noticed highest in the month of November (11.81). The higher prices indices were noticed during August to December. While lowest in April (4.37) followed by May. The monthly arrivals and prices of onion in Pune market shows great fluctuations and no any specific trend was observed.

KeY Words : APMC, Arrivals, Prices, Compound growth rate, Seasonal indices

How To Cite This PAPer : Daundkar, K.S., Bairagi, S.K. and Kolambkar, R.A. (2015). Trends in arrivals and prices of onion in Pune market. Internat. Res. J. Agric. Eco. \& Stat., 6 (2) : 300-303. 